\title{
Spatial Distribution Analysis of Syrian Immigrant Population Problem in Fatih - Istanbul
}

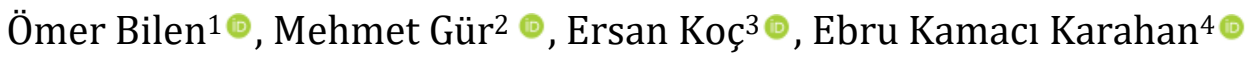 \\ ${ }^{1}$ Asst. Prof. Dr., Faculty of Architecture and Design, Bursa Technical University, Bursa, Turkey. (Principal contact for editorial \\ correspondence), Email: omer.bilen@btu.edu.tr \\ ${ }^{2}$ Dr., Faculty of Civil Engineering, Deparment of Geomatic Engineering, Yıldız Technical University, İstanbul, Turkey. Email: \\ gur@yildiz.edu.tr \\ ${ }^{3}$ Asst. Prof. Dr., Faculty of Architecture and Design, Bursa Technical University, Bursa, Turkey. Email: ersan.koc@btu.edu.tr \\ ${ }^{4}$ Asst. Prof. Dr., Faculty of Architecture and Design, Bursa Technical University, Bursa, Turkey. Email: ebru.karahan@btu.edu.tr
}

\begin{abstract}
Purpose

The paper reflects the impacts of the "Arab Spring" that broke out in Tunisia and Syria and led to the loss of more than 300,000 people. A wave of migration began in 2011, especially from Syria to its neighbouring countries including Turkey and Lebanon. Syrian migratory flows have caused social, economic, and ecological problems in the hosting countries. Turkey is one of the countries most affected by the wave of migration from Syria. Syrian refugees were unequally distributed or dispersed not only in leading metropolitan areas of western Turkey but also in many neighbouring cities in the southeast. The distribution of Syrian refugees in Turkish cities revealed considerable spatial heterogeneity and differences.
\end{abstract}

Design/Methodology/Approach

The sample size of the study is 953 and the margin of error of this sample size is \pm 3.17 at a $95 \%$ confidence level. Stratified simple random sampling was used. Interviews were

\section{Findings}

Fatih in İstanbul is one of the districts where Syrian immigrants most often settle. As part of the research on social risk mapping for Fatih District, immigrants - especially Syrian immigrants - have been identified as the main cause of problems by residents (the locals), with this group experiencing higher layoffs in terms of economic opportunities. Our analysis found that the main reason why Syrian immigrants are cited as a problem is "economic motivation". The rate at which Syrians are declared a problem in the districts of Fatih district is directly proportional to the distribution of the Syrian immigrant population.

\section{Research Limitations/Implications}

Time restriction, unfavourable weather conditions, missing information for socio economic status calculation, reluctance of women to join the survey.

Originality/Value

This study is the first research which examined spatially, how forced migration has an impact on local residents. Its results that can be useful for social measures towards urban planning and management to reduce the negative effects caused from forced migration population.

Keywords: Forced migration, Syrian refugees, urban security, social integration, spatial analysis 


\section{INTRODUCTION}

Due to its geographical location and historical background - amidst Asia, Africa, the Middle East, and Europe - Turkey has a multidimensional social, cultural, and geographical character. Turkey is a country, to which people who are forced to leave their homes after encountering several problems in their country of origin flee in order to benefit from relatively advanced public services. Those who have chosen to use Turkey either as a transit corridor to move to prosperous regions or as a country sometimes take up permanent residence. These processes generally lead to mutual acculturation processes. Among the most important reasons why Turkey is favoured by people who migrate from their country as the geography of interaction and settlement are internal and international stability, peace and political trust in the country, open-door policy, and protection of those in need. (Provincial Immigration Administration, Annual Immigration Report, 2013). Citizens of countries defined as irregular migrants in Turkey are from Iraq, Afghanistan, Pakistan, Syria, Moldova, Palestine, Myanmar, Georgia, and Iran. In this context, the scope of our research covers the most influential immigration wave of the last decade: "Syrian Forced Migrants".

On December 18, 2010, the turmoil and uprising - the so-called "Arab Spring" and/or "Democracy Wind", which led to the forced migration of the Syrian population from their country mainly to Turkey - began in Tunisia. The reflection of the "Arab Spring" in Syria caused the loss of more than 300,000 people. The total number of forced migrations of about 6,000,000 people is due to brutal and violent policies pursued by the Assad Syrian regime (Sandal, Hançerkıran, \& Tıraş, 2016). As a result of the bloody attacks by the Syrian regime against legitimate claims, about half of the country's population, whose population was 21.5 million in 2010, was evacuated from their homes. (Ağır \& Sezik, 2015). Today about $65 \%$ of the population defined as "displaced" by Ağır and Sezik (2015) had to abandon their country according to UNHCR data.

As already mentioned, Syrians are often forced to leave their country. Also, they chose Turkey as their first choice for asylum. Syrians who have immigrated to Turkey are considered "temporary protection classes" as critical for the country. The process of forced immigration, which began in 2011, is continuing while the speed of the process has slowed down. Due to civilian deaths in military attacks on Idlib, a new wave of immigration pressure on Turkey is arising. When the statistics on Syrian refugees and emergency shelters were announced, the actual migration to Turkey in 2012 was 14237. In 2013, the amount of temporarily protected Syrians rose to 200,000, and in 2014, this number was observed to reach 1,519,286.

While the number of Syrians taken under temporary protection reached $2,503,549$ in 2015 , this figure stood at $3,576,370$ in 2019 . Forced migration from Syria, which displayed a significant upward trend between 2011-2015, lost its rate of increase between 2015-2018. There is a slight decrease in the number of Syrians covered by temporary 
protection in 2019. (Provincial Immigration Administration, Annual Immigration Report, 2013).

The multifactorial waves of migration from Syria to Turkey with a high acceleration have made it difficult to mitigate, manage, and/or control them. For this reason, Syrian immigrants are scattered and dispersed in the major cities of the border regions, such as Şanlıurfa, Gaziantep, Hatay, and Kilis, and national metropolitan settlements such as Istanbul, Ankara, and İzmir. 3.72\% of the Turkish population are legal and registered Syrians under "temporary protection". The provinces with the highest number of Syrians are Istanbul $(563,791)$, Şanlıurfa $(471,955)$, Hatay $(442,909)$, and Gaziantep $(390,204)$.

The provinces where the proportion of Syrians in Turkey is over 3.72\% are Adıyaman, Adana, Hatay, Kayseri, Kahramanmaraş, Mardin, Osmaniye, Mersin, Şanlıurfa, Gaziantep, and Kilis (Çiftçi, 2018). While the number of Syrian forced immigrants is highest in Istanbul when looking at Syrian immigration rates by population, it is noteworthy that the Syrian forced immigration rate reaches $80 \%$ in Kilis province. Other provinces with a high percentage of the Syrian population in the total population are Hatay, Şanlıurfa, and Gaziantep. In these provinces, the percentage of Syrian forced immigrants in the total population is over $20 \%$.

Considering the distribution of Syrian forced immigrants in the cities, it is clear that there is no even and/or balanced distribution. When looking at the distribution of Syrians within cities and districts, parallel phenomena and location choices can easily be observed. For reasons of reasonable cultural and linguistic practice, forced Syrian immigrants prefer to live close to each other in certain ghettos and neighbourhoods in order to form cultural and economic clusters within the cities. Istanbul is the city that the majority of Syrian immigrants proportionally prefer. According to Kaya and Kıraç (2016), the vulnerability report of the Syrians in Istanbul, the districts with the highest proportion of the proportional distribution of the Syrian population are Küçükçekmece, Bağcllar, Fatih, Sultangazi, Esenyurt, and Başakşehir. These districts are the districts with over 15,000 Syrian forced immigrants.

The district of Fatih is one of the central districts of Istanbul affected by forced migration from Syria. According to Kavas (2019), Syrian forced immigrants live in varying densities in all 39 districts of Istanbul. One of the districts studied in the study, which was carried out as part of the TEPAV's 2018 project "Post-War Syrian Ghettos in Istanbul", is Fatih. According to the research results, the spatial distribution of the Syrian population in the district is summarized below;

- In the Fatih district, 30,747 Syrian immigrants are registered under temporary protection. Together with the unregistered population, this number reaches up to 55,000 .

- In the period between 2011 and 2016, it was determined that the Turkish population decreased and migrated to the districts of 
Beylikdüzü, Başakşehir, and Esenyurt due to Syrian forced immigration.

- The Syrian population is mainly concentrated in the districts of Akşemsettin, Aksaray, Ali Kuşçu, and Molla Gürani.

- The population in Akșemsettin neighbourhood is close to the Turkish population. The street Akşemsettin is called "Syria Street". $90 \%$ of Syrian craftsmen work and live in this street.

- The Syrian population rate in Ali Kuşçu neighbourhood is high, and the "Malta Bazaar" in the neighbourhood is called the "Syrian Bazaar".

- Yusufpaşa Street in the Aksaray neighbourhood is also a place where Syrians live densely together.

- Findikzade and the millet roads in the neighbourhood of Molla Gürani are also places where Syrian craftsmen are concentrated The effects of forced migration from Syria, which can be clearly comprehended through examples based on country, province, district, and neighbourhood, are quite visible and critical. In the settlements affected by migration, both demographic and cultural structures are changing, causing ghettoization that paves the way for the migration of the Turkish population to other neighbourhoods. Such observations are indications that social and cultural problems will arise in the coming years.

This study analyses the reactions of the inhabitants of the Fatih district in Istanbul to the spatial migration from Syria and the spatial distribution of these reactions. The data used in the study were collected within the project "Fatih Social Risk Map". Syrian migration is not one of the main objectives of this project, and the knowledge gained from the field study was obtained by evaluating the responses to the open question "What are the main problems of the Fatih district". In the context of this question, the profiles of persons who directly or indirectly indicated Syrian migration were examined in relation to the reception, gender, age, educational level, time spent living in the neighbourhood, time spent living in the district, and the neighbourhood in which they lived. The selected variables illustrate the effects of forced migration on the quality of urban life in physical, social, and economic contexts.

\section{BACKGROUND OF CONTEXTUAL FRAMEWORK}

Globalization, defined as a composite medium of social, cultural, and technological innovations brought about by the progress of communications infrastructure and transport and delivery systems, considerably deteriorates the distance factor. The concept of distance refers to the use of space and time. Reducing the time cost of the distances that have to be covered with different tools and vehicles leads to an easing of migratory movements and, consequently, to a restructuring of space (Cengiz, 2015). In the literature, there are different definitions of migration, which has important implications for the (re)design and 
redefinition of space. In the following subsection, the definition of migration in the context of forced and compelled migratory movements from Syria to the world, especially to the countries of the region, will be reviewed in relation to migration theories.

\section{Forced Migration from Syria in the Context of Migration Theories}

Immigration can simply be described as "human mobility". Migration is a concept that has existed since the beginning of time, social structures, and human history. And it has been differentiated over time according to its causes and results (Deniz, 2014). People abandon the place where they were born and live because of various problems and situations they encounter. So they might decide to move away from the place they live. Over time, a connection is established between people and the place where they live, based on personal and/or family history, memories, and experiences. Migration is a change in the place where the migrant lives. It is one of the important factors that change and/or damage the connection between the place where the person builds social and cultural bonds and ties (Ekici \& Tuncel, 2015). According to Özkarslı (2014), 5 different categories of immigration styles can be classified. These categories and subcategories are listed below:

- Destination: Internal migration, External migration

- Time: Temporary, Continuous

- Willpower: Voluntary, Compulsory

- Size: Person, Group, Family, Mass

- Legality: Legal, Illegal

According to the definition of Özkarslı (2014), forced Syrians can be defined as "forced - mass - external" migration depending on their characteristics. Migration movements from Syria have both legal and illegal characteristics, depending on the attitude of the country to be migrated. As a result of this migratory movement, some of the migrants will return when the process in Syria returns to normal, while others will definitely prefer to stay in their country. Therefore, this migration movement has both continuity and volatility.

As indicated in the paper's introduction, since the definition of migration has changed, the concept of migration has different characteristics among them in migration theories. When Syria's forced migration movement is evaluated in the context of migration theories, it can be associated with different theories in different ways. Ravenstein has attempted to reveal his migration-related analysis with generally applicable laws (Tobler, 1995). Some of the laws that can be associated with forced migration from Syria include the following:

- Migration is close to the countries of origin, such as Turkey and Lebanon, while resources that are remote from more immigration receive less immigration in European countries.

- Similarly, the vast majority of immigrants are harboured in countries like Turkey, which has a border with Lebanon. 
- Geographically similar routes are generally preferred for migratory movements.

Lee gathered the impulsive and attractive characteristics concerning immigration in 4 factors. These factors are those associated with the source of migration, the destination, disruptive barriers, and personal characteristics (Lee, 1966). When forced migration from Syria is evaluated in this context, the risk of violence and life security at the source of migration is the most important driving factor. The peaceful and stable environment in the destination countries is the main attractive factor. Factors that may occur during migration, human trafficking, and the choice of sea route as a migration route are intermediate obstacles. Qualified immigrants can legally enter European countries, but the legal transit of migrants defined as unqualified workers for these countries is not possible.

William Peterson is another theorist who attempts to explain migration with push-pull factors. Peterson has classified immigration taking into account individual and class differences (Savaş, 2006), (Çağlayan, 2006). Types of migration defined by Peterson (1958) include primitive, forced, and enforced (compelled), free (mass) migration. The Syrian migration movement corresponds to Peterson's definition of forced migration. Whereas he defines forced migration, Peterson demonstrates for example the violence of the Nazis against the Jews. The violence against the opposition by the regime in Syria is the main source of migration. Despite the existence of mass immigration from Syria outside the country, Peterson's definition of mass immigration does not fit this context.

The Immigration Systems Theory is an approach based on international relations that explains forced migration from Syria. This approach recognizes that there are historical relationships between the country of immigration and the country of destination, which provide the necessary infrastructure for pre-migration immigration. It is based on the former relations with French colonial relations, which may exist between African countries in the economic relations between Turkey and Germany. The underlying historical relations between Syria and cultural relations with Turkey are located within the relationship defined by the theory of the immigration system.

In this context is the forced migration that took place from Syria to Turkey:

- It depends on the historical and cultural relations between the two countries,

- While the brutality of the regime in Syria is a driving force, Turkey, which creates a peaceful and secure environment, is an attractive force.

- There are obstacles such as human trafficking and the risk of death during migration. 
- Individual characteristics of migration from Syria to Turkey in case of threat or on the permanence of migration of individuals are effective to bring migration to an end. Turkey welcomes all immigrants regardless of individual characteristics.

- The migration from Syria to Turkey has arisen from the need for security of life

\section{Impacts of Irregular Migration on Turkey and World Countries}

When studying the impact of irregular migration on countries, it is necessary to consider the conditions under which immigrants become immigrants. It is a fact that people who have become immigrants for reasons of war or conflict arrive in the destination countries with the financial assets they have left in their home countries. Consequently, the problems and negative effects of these problems that immigrants face in the destination country should be taken into account. The outstanding problems that Yllmaz (2011) cites in the report highlight the problems faced by Syrian immigrants:

- The presence of crowded families

- Children have to sell on the streets the items such as water and handkerchiefs due to the lack of a livelihood.

- Difficulties in paying the rent

- The difficulty of processes related to obtaining financial support from the public

- Those who cannot find accommodation are obliged to sleep in parks and gardens

- The most serious problem is that Syrian women and children have to beg for money and food in the streets.

These problems experienced by immigrants in their country of origin have the potential to create new problems for the destination country. The labour force structure in the destination country is one of the factors that will be affected by irregular migration. (Ceritoglu, Yunculer, Torun, \& Tumen, 2017) Migration from Syria has been studied in terms of its impact on the labour market in Turkey. According to this study, the rate of informal employment in Turkey decreased by $2.2 \%$ after migration. The main reason for this decline is that Syrian immigrants are employed informally because they do not have a formal work permit and are generally uneducated. While men who lost their jobs became unemployed, women lost their characteristics as workers.

In addition to the granting of work permits to Syrians, the balance on the labour market also brought about a change. In Turkey, where 1 million people need integration into the labour market, unemployment is a major problem. In cities with high unemployment rates, Syrians are rival to local workers and unemployed classes. The number of companies founded by Syrians has increased since 2011. Although these companies would prefer to employ Syrians who are cheaper workers, they could lead to an increase in informal employment. 
The Syrians' competition in the labour market also creates social problems. In cities where the unemployment rate is high, the idea that Syrians occupy local jobs and other negative thoughts can trigger social conflicts. The most important solution to overcome these problems is to create a strong, harmonious, and equitable labour market. This will ensure the social and economic integration of the Syrians. (Özpınar, Çilingir, \& Düşündere, 2016). At the beginning of the migration period in Syria, it was not on the agenda as an immigration problem in Turkey. The spread of immigrants to all cities in the country has made this an important problem.

The problem of Syrian immigrants in relation to the economic, social, and political context in Turkey is not only a domestic problem of our country but also a global problem. The European Union and the United Nations are important international and global players who must play an active role as cost generators and providers of solutions to these problems. Despite the fact that the European Union has committed itself to support migrants in Turkey with 3 billion Euros, such a commitment has not been fulfilled so far (Paksoy \& Gümrah Can Başdağ, 2019). Simply because the migrants in Turkey might encounter problems or a step towards creating better opportunities for migration to the countries of the European Union is possible, if the predictions are to be heard. Therefore, Syrian refugees in Turkey are primarily a problem in other countries, including the European Union. The analysis of the report on the economic impact of Syrian Immigration on Turkey, prepared by ORSAM in 2015, has highlighted the impact of migration with its positive and negative aspects. The migration effects that come to the fore in this report are listed below (Öztürkler \& Göksel, 2015).

- Except for Mersin, cities with large numbers of Syrian migrants receive less internal migration. This was due to the perception of increasing unemployment, rising costs of living, and declining security conditions in these cities.

- In the import and export balances of the cities, different effects occurred after migration. In Gaziantep, Adana, Kahramanmaraş, and Mardin, the import-export balance has changed positively in the direction of exports. Economic relations, especially with the countries of the Middle East and North Africa, have improved positively in the direction of exports due to Syrian traders. This situation also had positive political repercussions.

- The goal of reducing the class sizes targeted in education was negatively influenced. Class sizes increased on average by up to 1 to 5 times

- Locals working in the informal sector have lost their jobs. There has been a drop in wages.

- The new demand created by the Syrians and the investments made in the region, for this reason, expanded the labour market, 
even if only partially, and at the same time created new employment opportunities.

- The rise in food prices and rents in regions that experience high immigration had a negative impact on inflation.

- The locals indicate that health services are increasingly worsening and it is becoming more and more difficult to get health services.

One of the countries preferred by Syrian immigrants is Lebanon, where the problems caused by immigrants are gradually increasing. Lebanon's existing systems and infrastructure are not sufficient to meet the growing needs of immigrants. Migrants are also isolated from economic activities and society (Hamdar and Hejase, 2018). The impact of immigrants in Jordan has been assessed in the context of political, economic, sociocultural, and environmental factors, with the result that these four factors are interdependent. Although the economic effects increased social tensions, they also led to political intervention. The economic stagnation has had negative effects on the ecosystem and the use of natural resources. (Alshoubaki \& Harris, 2018). In Germany, it is considered an important problem that immigrants can work for relatively low wages in jobs that are equivalent to those of the native population. Unemployment rates for immigrant groups are high as immigrants do not have these qualifications, while those employed in Germany often work in occupations that require higher education and greater autonomy. Immigrants are confronted with the language, the equivalence of diplomas, and the legal inability to work in the host countries (Chatzichristou, 2018).

\section{METHODOLOGY}

The sample size of the study is 953 and the margin of error of this sample size is \pm 3.17 at a $95 \%$ confidence level. However, due to the limitations mentioned in the next section, a deterioration of the sampling design may lead to an increase in this rate.

The households in which the individuals to be interviewed live were determined using a stratified simple random sampling method. It is divided into 25 strata based on the quarters of the Fatih District. Depending on the population of the quarter, neighbourhoods with less than 15 samples are grouped as a single stratum under the other stratum. It was observed that the neighbourhoods grouped under the other were in the former Eminönü district and were generally in the workplace.

The interviews in the selected neighbourhoods of the sample were randomly distributed to the streets/streets, as the sampling frame was not available.

Population: Individuals aged 15+ living in Fatih District Sampling Method: Stratified simple random sampling Sample Frame: Streets in the neighbourhoods of Fatih District Sampling Unit: Individuals aged 15+ 
Sampling Features

- The share of household heads is $52.3 \%$, the share of other household members is $47.7 \%$.

- The percentage of women is $40 \%$ and the percentage of men is $60 \%$.

- The average age of men in the district is 25.08 years and 22.01 years for women.

- The average age of men in the neighbourhood is 22.52 years, that of women 16.8 years.

- The proportion of $15-30$ year-olds is $30 \%$, the proportion of 31 45 year-olds is $34.9 \%$ and the proportion of over 45 -year-olds is $35.1 \%$.

- The ratio of those who have completed elementary and elementary school is $36.9 \%$, the ratio of secondary and high school graduates is $48.3 \%$, and the ratio of graduates from vocational high schools and above is $14.8 \%$.

- $13.6 \%$ of the SES group calculated in $\mathrm{AB}, 69.4 \%$ in $\mathrm{C} 1-\mathrm{C} 2,17 \%$ in DE SES group is located, especially gender in the distribution of the sample by neighbourhood and demographic variables.

There were a few limitations to the study. These limitations are listed as follows.

- Based on the work plan of the field company, an attempt was made to complete the field study in 3 days.

- One of the obstacles experienced during the field studies was the unfavourable weather conditions in Istanbul at the time of the survey.

- Time restrictions in interviews, as women are reluctant to participate in the survey. For this reason, male persons were preferred in the household.

- SES results of some respondents; the income used to calculate the SES, profession, etc. could not be calculated because they did not answer their questions.

- In the question in which the immigrant problem was used as a dependent variable, it was assumed that those who state the most important problem of Fatih as an immigrant mean Syrians among other immigrants in Fatih.

\section{FINDINGS OF THE STUDY}

In the 2015 survey, the rate of those who say that they consider foreigners or immigrants to be the most important problem of the Fatih district is $20.7 \%$. This ratio differs spatially in terms of distribution by location. Among the problems grouped as foreigners, the rate of those who identify Syrians as problems is $41.0 \%$. The spatial distribution of those who identify Syrians as a problem also differs spatially in terms of the distribution of locations, as do those who identify foreigners as a problem. The neighbourhoods with $50 \%$ or more foreigners as the main 
problem are Muhsine Hatun, Nevbahar, Aksaray, Kalenderhane, and Molla Gürani. Among these neighbourhoods, the Aksaray and Molla Gürani neighbourhoods are the districts with the highest Syrian population. The regions where those who cite foreigners as a problem are $50 \%$ or more, especially those that cite Syrians are Muhsine Hatun, Molla Hüsrev, Kalenderhane, Balat, Ayvansaray, Ali Kuşçu, Yavuz Sultan Selim, Sümbül Efendi, Karagümrük, Topkapı, Akşemsettin, Hirkai Şerif, Silivrikapı, and Koca Mustafapaşa. To these districts belong Akşemsettin and Ali Kuşçu, which represent the densest Syrian population. Examining the distribution of the districts in which the immigrant problem is most strongly perceived, it is obvious that these districts are concentrated in the centre of Fatih.

It is observed that there is a linear relationship between the spatial distribution of the immigrant problem and immigrant density. The districts of Muhsine Hatun, Aksaray, and Kalenderhane, which are among the districts where most immigrants live, were defined as urban deterioration areas at the time the study was conducted. In the interviews with the district municipalities, it is stated that the districts İskenderpaşa and Molla Gürani are now becoming collapsed areas. It has been noted that the immigrant population is finding housing primarily in the deteriorated areas and accelerating the transformation to the deteriorated area in other regions where they are settled and densely populated.

Figure 1. Distribution of people who define "Foreign People" and "Syrians" as Fatih District's most important problem.

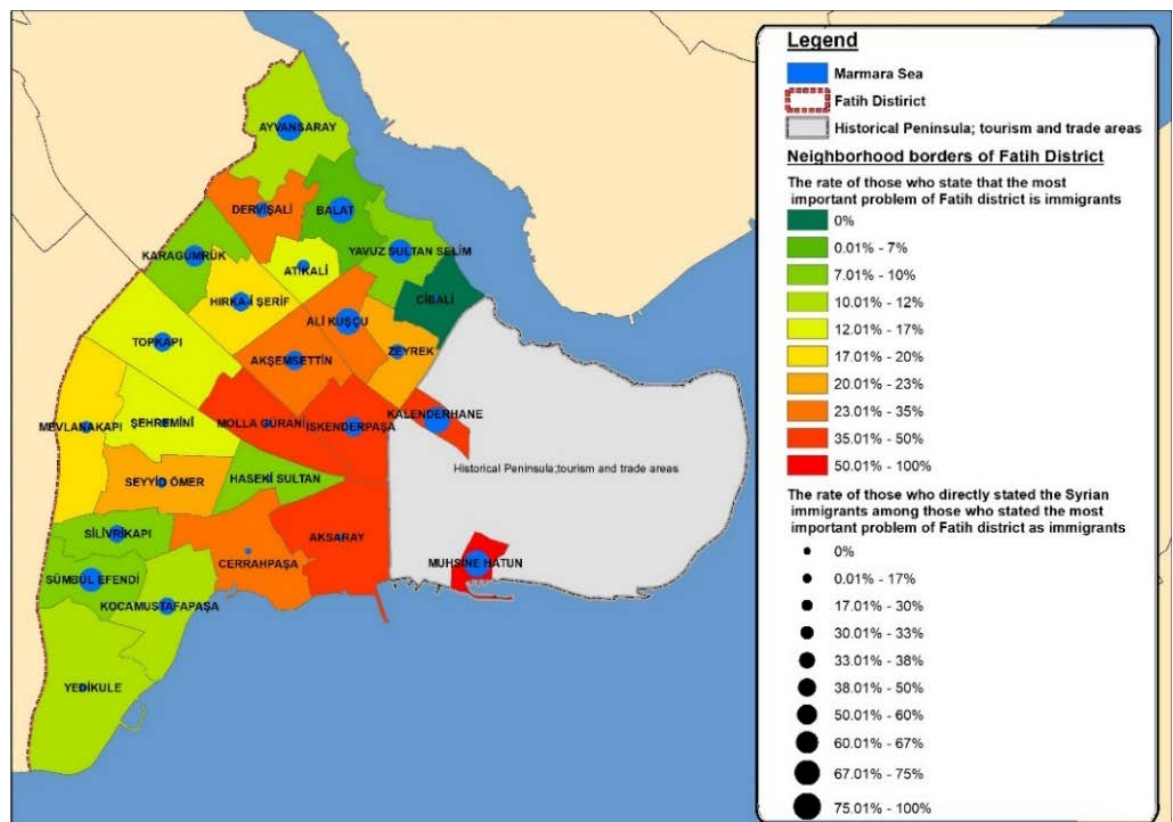

The second variable that, according to spatial distribution, causes differentiation in specifying strangers as a problem is "homeownership" (Chi-square $=5.883, \mathrm{df}=2, \mathrm{p}=0.054$ ). The percentage of those who specify foreigners as a problem is listed as follows: Living without paying rent, tenants, and landlords. It is assumed that non-house owners see Syrians as a threat, which is supported by the fact that, as outlined in the 
conceptual framework section, rents are rising and food prices are increasing in areas with high immigrant populations. The third variable that causes differentiation in specifying Syrians as a problem is "gender". Men were 2 times more likely than women to specify Syrians as a problem (Chi-square $=8.501, \mathrm{df}=1, \mathrm{p}=0.004$ ). The greater problem of job security for men can be linked to this result. It can be seen that economic concerns come to the fore in both the " specifying Syrians as a problem" and the "specifying immigrants as problems in general".

In the studies conducted today in the Fatih district, it is noted that the dissatisfaction from Syrian immigrants continues to increase and the natives migrate to different districts or districts in the neighbourhoods where Syrians live only sparsely. These findings clearly show the impact of the migrant problem caused by forced migration on the economic dimension of urban quality of life. It is evident that the decline in the economic dimension of urban quality of life will have a negative impact not only on the urban quality of life but also on the social dimensions.

Decision tree modelling has been used to determine the profile of those who have identified foreigners as a problem. In the modelling study, the state of specifying foreigners as a problem was used as a dependent variable $(0=$ Do not rate foreigners as a problem, $1=$ Rating foreigners as a problem). The independent variables used are homeownership, age, gender, length of stay in the district, educational status, and length of stay in the neighbourhood.

As a result of modelling studies, the decomposition of the model obtained with the CRT algorithm was accepted as successful. According to the model results, the most effective factor for seeing foreigners as a problem was determined as "homeownership". The second effective factor to see foreigners as a problem was determined as "age".

Corresponding to the model results, the possibilities to specify strangers as problems are listed below:

- Tenant without renting=\%35.3

- Homeowner/Tenant and age $>24.5=\% 22.0$

- Homeowner/Tenant and age $<=24.5=\% 10.4$

According to the results of the decision tree model, the last variable that is effective in identifying immigrants as a problem is age. The fact that persons over 24.5 years of age are a working population, which appears as a threshold value, should also be taken into account.

\section{CONCLUSION}

Irregular Syrian migration is not a phenomenon that is occurring for the first time in Turkey.

The political and military tensions in Iraq in the 1990s forced tens of thousands of immigrants to move to the Turkish border. Especially after the massacre in Halabja in 1988, there were massive waves of immigration. In this respect, our case describes a chapter in which we can explore how to develop a holistic approach with migrants who are 
welcomed with conscientious, humanitarian, and historical responsibility within the borders of our country.

The fact that the Anatolian geography, which we referred to in the introduction as "crossroads, corridor of passage and interaction pot", raises the question of "what impact the estimated total number of immigrants based on the estimated 5-6 million in the sociology and cultural geography of the country will have in the near future". Another key question that we would like to highlight is that the phenomenon of immigration if successfully managed, will force an enrichment of cities in terms of social relations, economic diversity, and cultural assets. Thus, a place that is not migrated as the first choice actually means a place that is not preferred among the migration options. It can be ascertained that the countries of the American continent, artificially and brutally constructed over the last centuries exclusively with waves of immigration, perceived immigrants as economic, social, and cultural catalysts. In the present study, we believe that this perception has not been directly investigated. Furthermore, we believe that when there are differences between countries of origin and destination in terms of cultural environments such as languages, religions, etc., mass migration flows pose valuable questions to defined new reservoirs of resources about what types of test, conflict, compromise, and synergy areas can be created. In summary, we can stress that regular or irregular migration can reveal both the opportunities and the threats that lead us to reflect on effective and beneficial models of migration management that are only possible in political ecosystems where cultural conflicts or codes of racial hatred can be suppressed.

Syrians who had to leave their country because of the ongoing repression in the Syrian civil war and the regime are problematic not only for Turkey but also for the industrialized countries. The literature review shows that the countries most affected by forced migration from Turkey, such as Lebanon, Jordan, and European countries, are not fully prepared for this phenomenon. Turkey has been relatively late in taking measures for the economic and social integration of Syrian immigrants. In this study, the integration problems of Syrian forced immigrants were discussed and evaluated in the context of the study.

The results of the research conducted in 2015 show that initiatives to integrate Syrian migrants should be taken at that time. Today it is clear that not enough attempts have been made since this issue was discussed. It is clear that due to Syrian immigration, negative changes in the social, economic, and demographic structure have been observed in the Fatih district, the case study area. The density of immigration is increasing, and the level of dissatisfaction among the local population is rising Syrians are considered a problem because of economic concerns. This situation shows how important it is to take the necessary steps to ensure the economic integration of Syrian migrants.

However, Syrian migration does not have only negative aspects. The expansion of the labour market and the opening of new markets abroad 
by Syrian traders are remarkable positive effects. It is advantageous to share these positive effects with the public in areas where Syrian immigrants are concentrated. At the same time, measures should be taken to inform Syrians who work informally that they are dismissing the natives or posing a threat to the workforce. Unregistered employment should be prevented. Syrian immigrants are also seen as a security threat, which may pose a risk for future social conflicts. The necessary measures should therefore be taken to address this problem. Syrian women and children should not be forced to beg. Begging is one of the irregularities that increase the perception of crime.

In areas where Syrians live close together, measures should be taken to eliminate disruptions to health services. Problems that arise in the education system should be identified locally and solved with proper interventions. It should not be forgotten that Syrians flee and immigrate from the pressure and violent environment in their countries. International efforts should be made to end the civil war in Syria. Steps such as the creation of a safe zone to allow Syrian immigrants to return to their countries should be taken quickly.

The study clearly shows that in places where the immigrant population is concentrated, the quality of urban life decreases in physical, social, and economic terms. Ensuring a more controlled spatial distribution of immigrants, which has a negative impact on the quality of urban life, ensuring the integration of immigrants into the city, legalizing the participation of immigrants in economic activities will at least contribute to reducing the problems that will arise in relation to urban quality of life.

\section{ACKNOWLEDGEMENTS}

Special thanks to the Method Research Company for allowing us to conduct the field process of this project free of charge.

\section{CONFLICT OF INTEREST}

No conflict of interest was declared by the authors

\section{FINANCIAL DISCLOSURE}

The authors declared that this study has received no financial support. Method Research Company conducted the field process of this project free of charge.

\section{ETHICS COMMITTEE APPROVAL}

"Ethics committee approval was not required for this article"

\section{LEGAL PUBLIC / PRIVATE PERMISSIONS}

"In this research, the necessary permissions were obtained from the relevant participants (individuals, institutions and organizations) during the survey, in-depth interview, focus group interview, observation or experiment." 
Spatial Distribution Analysis of Syrian Immigrant Population Problem in Fatih - İstanbul

\section{REFERENCES}

Ağır, O., \& Sezik, M. (2015). Suriye' den Türkiye' ye yaşanan göç dalgasından kaynaklanan güvenlik sorunları. Birey ve Toplum, 5(9), 95124.

Alshoubaki, W., \& Harris, M. (2018). The impact of Syrian refugees on Jordan: A framework for analysis. 11(2), 154-179. https://doi.org/10.14254/2071-8330.2018/11-2/11

Cengiz, D. (2015). Spatial effect of forced migration and perception of local community; Case of Kilis. Turkish Studies, 10, 101-122.

Ceritoglu, E., Yunculer, H. B. G., Torun, H., \& Tumen, S. (2017). The impact of Syrian refugees on natives' labour market outcomes in Turkey: evidence from a quasi-experimental design. 1-28. https://doi.org/10.1186/s40173-017-0082-4

Chatzichristou, M. (2018). The Impact of Syrian Refugees on German Labour Market. Erasmus Unıversiteit Rotterdam.

Çiftçi, H. (2018). Türkiye Cumhuriyeti vatandaşlarının Suriyeli sığınmacılara yönelik tutum, algı ve empatik eğilimlerinin analizi. İnsan ve Toplum Bilimleri Araştırmaları Dergisi, 7(3), 2232-2256.

Deniz, T. (2014). Uluslar arası göç sorunu perspektifinde Türkiye. TSA, 18(1), 175-204.

Ekici, S., \& Tuncel, G. (2015). Göç ve insan. Birey ve Toplum, 5(9), 9-22.

Kavas, A., Avşar, İ., Kadkoy, O., \& Bilgiç, E. Ç. (2019). İstanbul' da Suriyeliler ve Savaş Sonrası Suriye Gettoları.

Kaya, A., \& Kıraç, A. (2016). İstanbul'daki Suriyeli Mültecilere İlişkin Zarar Görebilirlik Değerlendirme Raporu.

Lee, E. S. (1966). A theory of migration. Demography, 3(1), 47-57.

Özkarslı, F. (2014). "Suriye'den Türkiye'ye göç ve Suriyelilerin enformel istihdamı" Artuklu Üniversitesi.

Özpınar, E., Çilingir, Y. S., \& Düşündere, A. T. (2016). Syrians in Turkey: Unemployment and Social Cohesion.

Öztürkler, H., \& Göksel, T. (2015). Suriyeli Mültecilerin Türkiye’ye Ekonomik Etkileri: Sentetik Bir Modelleme.

Paksoy, H. M., \& Gümrah Can Başdağ. (2019). The neccessity of externalization of costs of Syrian refugees. Gaziantep University Journal of Social Sciences, 18, 1113-1120.

Petersen, W. (1958). A general typology of migration. American Sociological Review, 23, 256-266.

Sandal, E. K., Hançerkıran, M., \& Tıraş, M. (2016). Türkiye' deki Suriyeli mülteciler ve Gaziantep ilindeki yansımaları. Gaziantep University Journal of Social Sciences, 15(2), 461-483.

Savaş, Ç. (2006). Göç Kuramları, Göç ve Göçmen İlişkisi. ÍLKE, (17).

Tobler, W. (1995). Migration: Ravenstein, Thornthwaite, and beyond. Urban Geography, 16(4), 324-343. 
Ylllık Göç Raporu. (2013). (2020, January 10). https://www.goc.gov.tr /2013_yillik_goc_raporu.pdf

Yılmaz, H. (2011). Türkiye' de Suriyeli Mülteciler - İstanbul Örneği - (C. 90).

\section{Resume}

Ömer Bilen received his B. Arch and M. Arch from Ylldiz Technical University in the major of statistics. Ömer Bilen received his PhD degree from Ylldiz Technical Universtiy in the major of urban planning. He currently works as an Assist. Prof. Dr. at Urban and Regional Department of Bursa Technical University.

Mehmet Gür currently works at Ylldız Technical University, Deparment of Geomatic Engineering, Division of Land Management as a researcher. He received his M. Arch and PhD degrees from Ylldiz Technical University, Turkey. His main areas of research are land management, urban transformation, land valuation and GIS.

Ersan Koç is assistant professor at Bursa Technical University, Department of Urban and Regional Department. His major research topics are urban design and implementation, urban-regional-global geography and planning theory, risk society and resilient cities, industrial history, innovative clusters and local development models, technology, and space.

Ebru KAMACI KARAHAN is assistant professor at Bursa Technical University, Turkey. She completed her PhD dissertation at Middle East Technical University entitled "Re-reading Urbanization Experience of Istanbul through Chancing Residential Mobility Behavior of Households". She researches housing with particular focus on the intra-urban mobility, migration, GIS and socio-spatial changes. 